\title{
Enhancing glutamine production by optimising the GS-GOGAT pathway in Corynebacterium glutamicum and $\mathrm{NH}_{4}{ }^{+}$-limited fermentation
}

\author{
Yunpeng $\mathrm{Liu}^{1}$, Lanxiao $\mathrm{Li}^{2}$, Jinduo Wang ${ }^{2}$, and Qingyang $\mathrm{Xu}^{2}$ \\ ${ }^{1}$ Tianjin University of Science and Technology \\ ${ }^{2}$ Affiliation not available
}

September 30, 2021

\begin{abstract}
Abstract: The GS-GOGAT pathway is a key metabolic pathway of glutamate and glutamine. Optimising this pathway, leading to metabolic flux to glutamine, can increase glutamine production and reduce the production of the by-product glutamate. The $\mathrm{NH}_{4}{ }^{+}$-limited fermentation process limits the concentration of $\mathrm{NH}_{4}{ }^{+}$to increase the activity of GS and further increase the yield of glutamine. The GS-GOGAT pathway was optimised by knocking out the GOGAT genes NCgl0181 and NCgl0182 and the glutaminase genes NCgl2395 and NCgl2500 and by integrating a copy of the GS gene glnAbsu from Bacillus subtilis and a copy of the glutamine synthase gene glnAlcb from Lactobacillus acidophilus into the genomic NCgl0182 and NCgl2500 sites. Furthermore, the pXT01 plasmid with the strong promoter tuf was used to overexpress glnAbsu and glnAlcb. To obtain an optimal $\mathrm{NH}_{4}{ }^{+}$-limited fermentation process, the effects of starting feeding with $\left(\mathrm{NH}_{4}\right)_{2} \mathrm{SO}_{4}$ at different times of fermentation and three $\left(\mathrm{NH}_{4}\right)_{2} \mathrm{SO}_{4}$ feeding strategies on glutamine fermentation were studied, and a $\mathrm{NH}_{4}{ }^{+}$-limited fermentation process that was the most suitable for glutamine fermentation was determined. After optimising the GS-GOGAT pathway, Corynebacterium glutamicum G-6 was subjected to the $\mathrm{NH}_{4}{ }^{+}$-limited fermentation process to greatly increase the production of glutamine. The yield of glutamine reached $98.7 \mathrm{~g} / \mathrm{L}$, which was $104.8 \%$ higher than that in the original strain GM34; the content of glutamate reached $4.5 \mathrm{~g} / \mathrm{L}$, which then decreased by $85.2 \%$; the GS activity increased significantly, and the sugar-acid conversion rate reached $41.2 \%$.
\end{abstract}

Enhancing glutamine production by optimising the GS-GOGAT pathway in

Corynebacterium glutamicum

and $\mathrm{NH}_{4}{ }^{+}$-limited fermentation

Abstract: The GS-GOGAT pathway is a key metabolic pathway of glutamate and glutamine. Optimising this pathway, leading to metabolic flux to glutamine, can increase glutamine production and reduce the production of the by-product glutamate. The $\mathrm{NH}_{4}{ }^{+}$-limited fermentation process limits the concentration of $\mathrm{NH}_{4}{ }^{+}$ to increase the activity of GS and further increase the yield of glutamine. The GS-GOGAT pathway was optimised by knocking out the GOGAT genes $N C g l 0181$ and $N C g l 0182$ and the glutaminase genes NCgl2395 and NCgl2500 and by integrating a copy of the GS gene $g l n A_{b s u}$ from Bacillus subtilis and a copy of the glutamine synthase gene $g l n A_{l c b}$ fromLactobacillus acidophilus into the genomic NCgl0182 and NCgl2500 sites. Furthermore, the pXT01 plasmid with the strong promoter $t u f$ was used to overexpress $g \ln A_{b s u}$ and $g \ln A_{l c b}$ . To obtain an optimal $\mathrm{NH}_{4}{ }^{+}$-limited fermentation process, the effects of starting feeding with $\left(\mathrm{NH}_{4}\right)_{2} \mathrm{SO}_{4}$ at different times of fermentation and three $\left(\mathrm{NH}_{4}\right)_{2} \mathrm{SO}_{4}$ feeding strategies on glutamine fermentation were studied, and a $\mathrm{NH}_{4}{ }^{+}$-limited fermentation process that was the most suitable for glutamine fermentation was determined. After optimising the GS-GOGAT pathway, Corynebacterium glutamicum G-6 was subjected 
to the $\mathrm{NH}_{4}{ }^{+}$-limited fermentation process to greatly increase the production of glutamine. The yield of glutamine reached $98.7 \mathrm{~g} / \mathrm{L}$, which was $104.8 \%$ higher than that in the original strain GM34; the content of glutamate reached $4.5 \mathrm{~g} / \mathrm{L}$, which then decreased by $85.2 \%$; the GS activity increased significantly, and the sugar-acid conversion rate reached $41.2 \%$.

Keywords: L-glutamine, Corynebacterium glutamicum, GS-GOGAT pathway, glutamine synthase, $\mathrm{NH}_{4}{ }^{+}-$ limited fermentation process

L-glutamine is a neutral amino acid of $\gamma$-carboxylamidation of L-glutamate. It is one of the 20 basic amino acids that compose biological proteins. It plays an important role in maintaining human function and life activities. Its content in the human body is very high, accounting for $61 \%$ of free amino acids[1-2]. In recent years, with the in-depth study of L-glutamine, it has been widely used in medicine, health food, feed, and other products[2]. As a potential new drug, L-glutamine is mainly used in the clinical treatment of gastrointestinal ulcers[3], relief for exercise fatigue[4], improvement of brain nerve function[5], and regulation of immunity of the body[6]; exogenous L-glutamine can stimulate immunoglobulin secretion and promote immune system reconstruction, such as in burns, AIDS, and arthritis as well as other immune system recovery[7]. The potential value of L-glutamine in cancer treatment lies in reducingto reduce the side effects of chemotherapy and radiotherapy[8]. With in-depth research of the physiological function and application range of L-glutamine, the demand and production of L-glutamine are increasing. In particular, the medicinal demand is very large; so, it has a broad market prospect.

The glutamine synthetase (GS)-glutamate synthase (GOGAT) pathway is an important metabolic pathway between glutamate and glutamine. There are two ways for microorganisms to absorb $\mathrm{NH}_{4}{ }^{+}[9-10]$; (1) the glutamate dehydrogenase (GDH) pathway: $\alpha$-ketoglutarate and $\mathrm{NH}_{4}{ }^{+}$produce glutamate under the catalysis of GDH, and (2) the GS-GOGAT pathway: glutamate and $\mathrm{NH}_{4}{ }^{+}$produce glutamine under the catalysis of GS, while one molecule of glutamine and one molecule of $\alpha$-ketoglutaric acid produce two molecules of glutamate under the catalysis of GOGAT. With a sufficient nitrogen source, microorganisms mainly rely on the GDH pathway to absorb $\mathrm{NH}_{4}{ }^{+}$. In the absence of nitrogen sources, the GS-GOGAT pathway is the main pathway for microorganisms to absorb $\mathrm{NH}_{4}{ }^{+}$[11-12]. Martin Teschet al .[10] showed that when the concentration of $\mathrm{NH}_{4}{ }^{+}$in the culture medium increased from 1 to $90 \mathrm{mmol} / \mathrm{L}$, the GDH enzyme activity in wild-type Corynebacterium glutamicum showed little change and remained at a high level, while the enzyme activity of GS and GOGAT decreased to less than $10 \%$ of the original activity. This shows that the activity of GS, the key enzyme in glutamine fermentation, is regulated by the concentration of $\mathrm{NH}_{4}{ }^{+}$. Ertan et al . [9] showed that when the concentration of $\mathrm{NH}_{4}{ }^{+}$in the culture decreased from 100 to $10 \mathrm{mmol} / \mathrm{L}$, the enzyme activity of GS increased by two times. Tesch[13] showed that $10 \mathrm{mmol} / \mathrm{L}$ is a critical concentration of $\mathrm{NH}_{4}{ }^{+}$; if $\mathrm{NH}_{4}{ }^{+}$is lower than $10 \mathrm{mmol} / \mathrm{L}$, then the absorption of $\mathrm{NH}_{4}{ }^{+}$by microorganisms mainly depends on the GS-GOGAT pathway. Schulz et al .[14] explored the effects of carbon and nitrogen sources on the activities of GS and GOGAT in C. glutamicum ATCC13032. They found that under the conditions of a sufficient carbon source and lack of a nitrogen source, the activity of GS and GOGAT increased by five and seven times, respectively. When both carbon and nitrogen sources were lacking, the activity of GS decreased by three times and that of GOGAT was not affected.

GS in C. glutamicum is affected by adenosine acylation[15]. AMP binds to the tyrosine residues on the peptide chain of GS in a covalent manner to produce GS (AMP)[16]. Under the influence of adenosine acylation, the catalytic properties of GS change significantly, and the activity of catalysing glutamate and $\mathrm{NH}_{4}{ }^{+}$to produce glutamine decreases significantly[12]. However, GS in Bacillus subtilis andLactobacillus acidophilus is not affected by adenosine acylation[17].

The main problems faced by L-glutamine fermentation include the following: (1) the GS-GOGAT pathway in C. glutamicum make glutamate and glutamine mutual transformation, which leads to high content of glutamate as a by-product, increased difficulty of glutamine extraction, and high costs. (2) Glutamine fermentation usually uses a large amount of $\mathrm{NH}_{4}{ }^{+}$, which reduces the enzyme activity of GS by adenosine acylation, and the bacterial growth activity is also affected by high concentrations of $\mathrm{NH}_{4}{ }^{+}$. As a result, the osmotic pressure becomes too high and bacterial growth activity weakens. These problems make it difficult 
for the production capacity and sugar-acid conversion rate of L-glutamine to reach the ideal effect.

In this study, to address the main problems of L-glutamine fermentation, the GS-GOGAT pathway of $C$. glutamicum was optimised by knocking out GOGAT genes NCgl0181 and NCgl0182 and glutaminase genes NCgl2395 and NCgl2500. A copy of the GS gene $g \ln A_{b s u}$ from B. subtilis and a copy of the glutamine synthase gene $g l n A_{l c b}$ from L. acidophilus were integrated at genomic NCgl0182 and NCgl2500 sites. Furthermore, the GS genes $g \ln A_{b s u}$ and $g \ln A_{l c b}$ from $B$. subtilis and L. acidophilus were overexpressed using pXT01 with the strong promoter tuf . Based on the effect of the above genetic modification and the characteristics of the GS-GOGAT pathway, an $\mathrm{NH}_{4}{ }^{+}$-limited fermentation process was designed, which effectively improved the activity of GS and bacterial activity and production capacity of glutamine. A schematic diagram of the GS-GOGAT pathway optimisation is shown in Fig. 1.

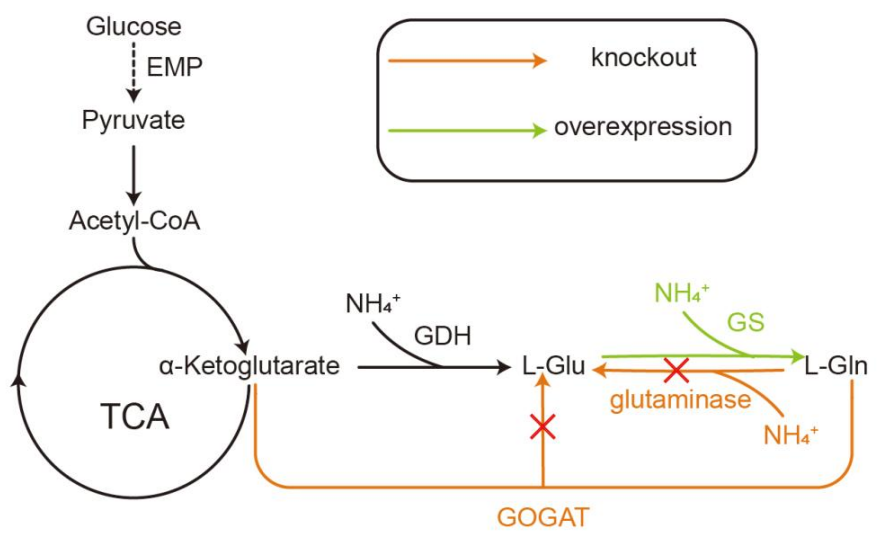

Fig. 1 The GS-GOGAT pathway and its optimisation methods

\section{Materials and methods}

\subsection{Materials}

\subsubsection{Strains and plasmids}

The strains and plasmids used in this study are shown in Table 1.

Table 1 strains and plasmids

Strain
GM34
G-1
G-2
G-3
G-4
G-5
G-6
G-7
Plasmid
pK18mobsacB
pK18mobsacB-[?] NCgl0181
pK18mobsacB[?] $N C g l 2395$
pXT01
pXT01-gln $A_{b s u}$
pXT01-gln $A_{l c b}$

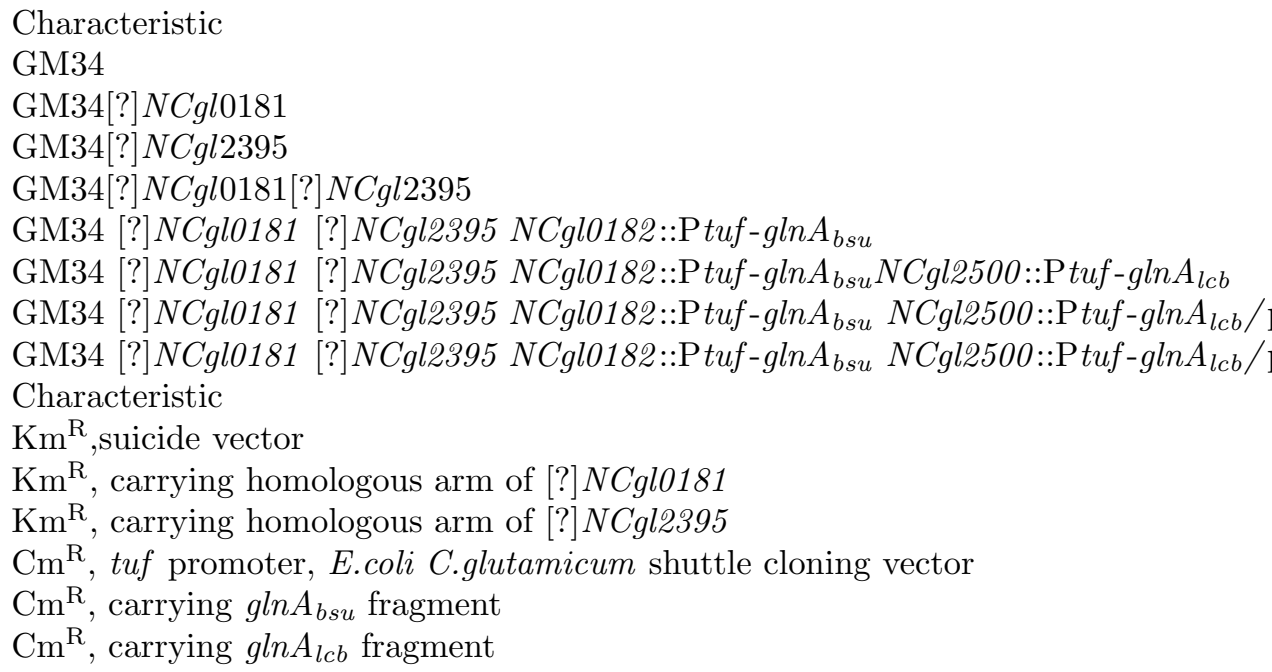


pK18mobsacB-NCgl0182::Ptufgln $A_{b s u}$ pK18mobsacB-NCgl2500::Ptufgln $A_{l c b}$
$\mathrm{Km}^{\mathrm{R}}$, carrying $N C g l 0182$ and $\mathrm{Ptuf}-g \ln A_{b s u}$ fragments

$\mathrm{Km}^{\mathrm{R}}$, carrying $N C g l 2500$ and $\mathrm{P} t u f-g \ln A_{l c b}$ fragments

\subsubsection{Primer}

According to the genes published by the KEGG, NCgl0181,NCgl0182, NCgl2500, and NCgl2395 of C. glutamicum ATCC 13032; bsu-glnA of B. subtilis subsp. subtilis 168; and lcb-glnA of Lactobacillus casei BL23 were studied. PCR amplification primers were designed according to the upstream and downstream nucleotide sequences of the above genes, as shown in Table 2.

Table 2 Primer sequence

\begin{tabular}{ll}
\hline Primer name & Primer sequence(5'-3') \\
N0up-s & ACGACGGCCAGTGCCAAGCTTCTATCTTCACGCACCATCATTTACA \\
N0up-a & GTGAAGCAATACCACCGAAGTAGTTGATTCAGAAGCCATCACAACCAAAC \\
N0down-s & GTTTGGTTGTGATGGCTTCTGAATCAACTACTTCGGTGGTATTGCTTCAC \\
N0down-a & GGTACCCGGGGATCCTCTAGATTCAGCAGAAATCGAGCCATAAGAC \\
N2up-s & ACGACGGCCAGTGCCAAGCTT GACATCATAAATGGTGGCTTTTGAG \\
N2up-a & AGCTGTTTGAATATTTTACGCCGC GTAGGCAAATGGCTTGGAAATACTT \\
N2down-s & AAGTATTTCCAAGCCATTTGCCTACGCGGCGTAAAAATATTCAAACAGCT \\
N2down-a & GGTACCCGGGGATCCTCTAGA CTGCAACAATCAAAGGCAACATAAG \\
bsu-glnA-s & CTGCAGGTCGACTCTAGAGGATCCATGGCAAAGTACACTAGAGAAGATATCG \\
bsu-glnA-a & CGCCAAAACAGCCAAGCTGAATTCTTAATACTGAGACATATACTGTTCGCGT \\
$l c b-g l n A-s$ & CTGCAGGTCGACTCTAGAGGATCCATGGGCGATGAAGCCGTCATCGAGC \\
$l c b-g l n A-\mathrm{a}$ & CGCCAAAACAGCCAAGCTGAATTCTGCCTTGCATCGCGAATTGTATTAA \\
N0182up-s & cgagctcggtaccggggatcc ACCCACAAGGATTCATCAAATACTC \\
N0182up-a & CCTTCGGATCTAAACGATCTGTTAAC ATCCAGCGGTTCTCCATTTTGTATT \\
N0182tuf-s & AATACAAAATGGAGAACCGCTGGATGTTAACAGATCGTTTAGATCCGAAGG \\
N0182 $g l n A-\mathrm{a}$ & GTGTTGACAGCAAATTTACGTTCACTTAATACTGAGACATATACTGTTCGCGT \\
N0182down-s & ACGCGAACAGTATATGTCTCAGTATTAAGTGAACGTAAATTTGCTGTCAACAC \\
N0182down-a & TTGTAAAACGACGGCCAGTGCC ACTGCTACAGGGAGTGCAGTTTCAC \\
N2500 up-s & cgagctcggtacccgggatcc AAAATCGGTGTCATTACCTTCCCAG \\
N2500 up-a & CCTTCGGATCTAAACGATCTGTTAACCAGTGGTGTTGTTCTCTACAACGAG \\
N2500tuf-s & CTCGTTGTAGAGAACAACACCACTGGTTAACAGATCGTTTAGATCCGAAGG \\
N2500glnA-a & ATCTGCTGACCCTTTTCCAAAGTGT TTACCAATTCATGTAGCGTTGGC \\
N2500down-s & GCCAACGCTACATGAATTGGTAA ACACTTTGGAAAAGGGTCAGCAGAT \\
N2500down-a & TTGTAAAACGACGGCCAGTGCC GAACAGCTCCAGGCCATCAATAGAT \\
\hline
\end{tabular}

\subsubsection{Fermentation culture medium of L-glutamine}

The seed culture medium was glucose $25 \mathrm{~g} / \mathrm{L}$, corn pulp dry powder $15 \mathrm{~g} / \mathrm{L}$, soybean meal hydrolysate 15 $\mathrm{mL} / \mathrm{L}, \mathrm{K}_{2} \mathrm{HPO}_{4} \cdot 3 \mathrm{H}_{2} \mathrm{O}$, and $\mathrm{MgSO}_{4} \cdot 7 \mathrm{H}_{2} \mathrm{O} 1 \mathrm{~g} / \mathrm{L}$.

The fermentation culture medium was $\mathrm{K}_{2} \mathrm{HPO}_{4} \cdot 3 \mathrm{H}_{2} \mathrm{O} 1.8 \mathrm{~g} / \mathrm{L}, \mathrm{VB} 10.1 \mathrm{mg} / \mathrm{L}$, soybean meal hydrolysate 10 $\mathrm{mL} / \mathrm{L}$, corn pulp dry powder $4 \mathrm{~g} / \mathrm{L}, \mathrm{MnSO}_{4} \cdot \mathrm{H}_{2} \mathrm{O} 10 \mathrm{mg} / \mathrm{L}, \mathrm{FeSO}_{4} 10 \mathrm{mg} / \mathrm{L}, \mathrm{ZnSO}_{4} 5 \mathrm{mg} / \mathrm{L}$, and $\mathrm{MgSO}_{4} \cdot 7 \mathrm{H}_{2} \mathrm{O}$ $1 \mathrm{~g} / \mathrm{L}$.

\subsection{Method}

\subsubsection{Construction of the NCglO181 knockout strain}

(1) Construction of the $p K 18 m o b s a c B[?] N C g l 0181$ vector 
The genome of C. glutamicum GM34 was used as the template, and N0up-s, N0up-a, N0down-s, and N0downa were used as the upstream and downstream homologous arm amplification primers of NCgl0181 (in which the 5' ends of NOup-s and N0down-a were added into the linear vector homologous sequences of restriction endonuclease XbaI and HindIII, and NOup-an and NOdown-s had an overlapping region of 25bp). Upstream and downstream homologous arms were amplified using PCR. Using the amplified upstream and downstream homologous arms as templates and NOup-s and NOdown-a as primers, overlapping PCR was carried out to obtain the overlapping fragment [?]NCgl0181.

The linear vector was obtained by double restriction endonuclease digestion at the XbaI and HindIII sites of $p K 18 \mathrm{mobsacB}$. The linear vector and overlapping fragment [?] NCgl 0181 were recombined and intro-

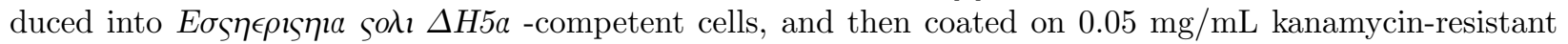
plate medium. Single colonies carrying the recombinant plasmids were screened and cultured in BHI liquid medium, and the plasmids were extracted.

\section{(2) NCgl0181 knockout}

The $p$ K18mobsacB[?]NCgl0181 was transformed into GM34-competent cells by electroporation. The bacteria were coated on $0.01 \mathrm{mg} / \mathrm{mL}$ kanamycin-resistant plate medium, and the single colonies with single crossover were screened.

A single colony with a single crossover was placed in BHI liquid medium and cultured at $32^{\circ} \mathrm{C}$. Cells were cultured for 2, 4, and $6 \mathrm{~h}$, and $50 \mu \mathrm{L}$ of fermentation broth was coated on the BHI liquid medium plate containing $15 \%$ sucrose, and the single colony was screened for double crossover.

\subsubsection{Construction of the NCgl2395 gene knockout strain}

The method used was the same as that provided in 1.2.1.

\subsubsection{Integrating a copy of $g \ln A_{b s u}$ at the genome $N C g l 0182$ site}

The method used was the same as that provided in 1.2.1.

\subsubsection{Integrating a copy of $g \ln A_{l c b}$ at the genome $N C g l 2500$ site}

The method used was the same as that provided in 1.2.1.

\subsubsection{Overexpression of the heterologous GS gene by pXT01}

\subsubsection{Overexpression of $g \ln A_{b s u}$ using pXT01}

\section{(1) Construction of pXT01-gln $A_{b s u}$}

The genome of B. subtilis was used as a template, andbsu-glnA-s and $b s u-g \ln A$ - $a$ were used as upstream and downstream amplification primers (the 5' ends of upstream and downstream amplification primers were added to the linear vector homologous sequences of restriction endonucleases BamHI and EcoRI). The $g l n A_{b s u}$ fragment with a length of 1335 bp was amplified by PCR.

The linear vector was obtained by double restriction endonuclease digestion at the BamHI and EcoRI sites of pXT01. The linear vector was recombined with the $g l n A_{b s u}$ fragment and introduced into $E$. solı $\Delta H 5 a$ -competent cells coated on $0.0005 \mathrm{mg} / \mathrm{mL}$ chloramphenicol-resistant plate medium. Single colonies carrying recombinant plasmids were screened and cultured in BHI liquid medium, and the plasmids were extracted.

Construction of the overexpression $g \ln A_{b s u}$ strain

pXT01-gln $A_{b s u}$ was transformed into GM34- competent cells by electroporation, and the bacteria were coated on a $0.0001 \mathrm{mg} / \mathrm{mL}$ chloramphenicol-resistant plate medium, and single colonies were screened for the successful introduction of pXT01-gln $A_{b s u}$.

\subsubsection{Overexpression of $g \ln A_{l c b}$ using pXT01}

The method used was the same as that provided in 1.2.5.1. 


\subsubsection{Strain culture method}

The strain was inserted into the bevel culture medium from the bacteria preservation tube of $20 \%$ glycerol for activation, and the culture conditions were $32^{\circ} \mathrm{C}$ for $12 \mathrm{~h}$.

Three $1 \mathrm{~L}$ triangular flasks were used as the primary seed shaking flask, and the bacteria on the bevel culture medium were inserted into the primary seed shaking flask. Shaker culture conditions were $32^{\circ} \mathrm{C}, 12 \mathrm{~h}, \mathrm{pH}$ 7.0 , and $220 \mathrm{rpm} / \mathrm{min}$.

Secondary seed culture was carried out in a $5 \mathrm{~L}$ fermenter. First, $300 \mathrm{~mL}$ of the primary seed liquid was poured into a $5 \mathrm{~L}$ fermenter for secondary seed culture. The culture medium volume was $2 \mathrm{~L}$, and the culture conditions were as follows: $34^{\circ} \mathrm{C}, \mathrm{pH} 7.0$, dissolved oxygen $30-50 \%$, culturing until $\mathrm{OD}_{600}$ reached 40 .

Fermentation culture was carried out in a $5 \mathrm{~L}$ fermenter. The inoculation amount was $20 \%$, the culture medium system was $3 \mathrm{~L}$, and the culture conditions were $34^{\circ} \mathrm{C}, \mathrm{pH} 7.0$, and dissolved oxygen $30-50 \%$.

\subsection{7 $\mathrm{NH}_{4}{ }^{+}$-limited fermentation process}

$\mathrm{NH}_{4}{ }^{+}$is a key factor in glutamine fermentation. $\mathrm{NH}_{4}{ }^{+}$is needed to catalyse the production of glutamine by GS, but a high concentration of $\mathrm{NH}_{4}{ }^{+}$affects bacterial growth and reduces the activity of GS. Under a low concentration of $\mathrm{NH}_{4}{ }^{+}$, the activity of GS is high; however, if the concentration of $\mathrm{NH}_{4}{ }^{+}$is too low, it reduces the production of glutamine. To solve the contradiction of $\mathrm{NH}_{4}{ }^{+}$concentration during fermentation and improve the activity of GS, an $\mathrm{NH}_{4}{ }^{+}$-limited fermentation process was designed, and two groups of experiments were carried out with the following different $\left(\mathrm{NH}_{4}\right)_{2} \mathrm{SO}_{4}$ feeding strategies: (1) $\left(\mathrm{NH}_{4}\right)_{2} \mathrm{SO}_{4}$ was fed uniformly 0,2 , and $4 \mathrm{~h}$ after fermentation. (2) The following three $\left(\mathrm{NH}_{4}\right)_{2} \mathrm{SO}_{4}$ feeding strategies were used: uniformly fed, intermittently fed, and gradient-fed. The glutamine fermentation yield, glutamate content, $\mathrm{NH}_{4}{ }^{+}$concentration, and GS activity obtained using the above fermentation strategies were analysed, and the most suitable $\mathrm{NH}_{4}{ }^{+}$-limited fermentation process was obtained.

\subsubsection{Calculation of the sugar-acid conversion rate}

\section{Hosted file}

image2.wmf available at https://authorea.com/users/438625/articles/539774-enhancingglutamine-production-by-optimising-the-gs-gogat-pathway-in-corynebacterium-glutamicumand-nh4-limited-fermentation

where SA is the sugar-acid conversion rate $(\%), \rho$ is the mass concentration of $\mathrm{L}$-glutamine $(\mathrm{g} / \mathrm{L}), \mathrm{V}$ is the total volume of fermentation broth $(\mathrm{L})$, and $\mathrm{m}$ is the total sugar consumption quality.

\subsubsection{Determination of glutamine production by high performance liquid chromatography}

Pre-treatment of the fermentation broth: The fermentation broth was centrifuged at 13,000 r/min for $2 \mathrm{~min}$, and the supernatant was obtained.

Derivative method: $200 \mu \mathrm{L}$ of derivative buffer, $10 \mu \mathrm{L}$ of sample, and $300 \mu \mathrm{L}$ of derivative agent were added to the ep tube, mixed well, and bathed at $65^{\circ} \mathrm{C}$ for $1 \mathrm{~h}$, and then the temperature was reduced to $25^{\circ} \mathrm{C}$. Next, $690 \mu \mathrm{L}$ of constant volume buffer was added, and the solution was mixed well.

The Agilent C18 $(15 \times 4.6 \mathrm{~mm}, 3.5 \mu \mathrm{m})$ chromatographic column was used with a mobile phase of $4.1 \mathrm{~g} / \mathrm{L}$ sodium acetate solution and $50 \%$ acetonitrile. Other conditions were a derivative agent 2,4dinitrofluorobenzene, a column temperature of $33^{\circ} \mathrm{C}$, a flow rate of $1 \mathrm{~mL} / \mathrm{min}$, and a detection wavelength of $360 \mathrm{~nm}$.

\subsubsection{Determination of the $\mathrm{NH}_{4}+$ concentration in fermentation broth}

The method used was the same as that provided in 1.2.9.

\subsubsection{Determination of GS activity}


GS activity was determined using a GS kit (Suzhou Keming Biotechnology Co., Ltd.). In the presence of ATP and $\mathrm{Mg}^{2+}$, GS catalyses $\mathrm{NH}_{4}{ }^{+}$and glutamate to synthesise glutamine, which is further converted to $\gamma$-glutamyl hydroxamic acid, and the complex formed with iron under acidic conditions has a maximum absorption peak at $540 \mathrm{~nm}$, which was determined by a multifunctional enzyme labelling instrument (TECAN, Infinite 200PRO). The unit of enzyme activity was defined as $1 \mu \mathrm{mol} \gamma$-glutamyl hydroxamic acid produced per hour in every $\mathrm{mL}$ reaction system per $\mathrm{g}$ of tissue.

\section{Results and discussion}

\subsection{Effect of optimising the GS-GOGAT pathway on glutamine fermentation}

\subsubsection{Effect of knocking out NCgl0181 and NCgl2395 on glutamine fermentation}

\section{Hosted file}

image3.emf available at https://authorea.com/users/438625/articles/539774-enhancingglutamine-production-by-optimising-the-gs-gogat-pathway-in-corynebacterium-glutamicumand-nh4-limited-fermentation

Fig. 2 Effects of knocking out $N C g l 0181$ and $N C g l 2395$ genes on bacterial growth $\left(\mathrm{OD}_{600}\right)$

As shown in Fig. 2, the growth of the original strains GM34, G-1, and G-2 was roughly the same. Due to the use of the biotin sub-appropriate process, the biotin content was limited, and the logarithmic growth phase of the four strains ended in approximately $14 \mathrm{~h}$, and the highest $\mathrm{OD}_{600}$ was approximately 102 . In the later stage of fermentation, the $\mathrm{OD}_{600}$ decreased slightly due to biotin deficiency and bacterial ageing. Under the same culture medium and method, the bacterial growth was basically the same, which indicated that NCgl0181 and NCgl2395 were not necessary for the growth and metabolism of GM34, and that their knockout had no adverse effect on bacterial growth.

\section{Hosted file}

image4.emf available at https://authorea.com/users/438625/articles/539774-enhancingglutamine-production-by-optimising-the-gs-gogat-pathway-in-corynebacterium-glutamicumand-nh4-limited-fermentation

Fig. 3 Effect of knocking out the $N C g l 0181$ and $N C g l 2395$ genes on glutamine and glutamate production

As shown in Fig. 3, the glutamine yield of GM34 was $48.2 \mathrm{~g} / \mathrm{L}$, and the by-product glutamate was as high as $30.4 \mathrm{~g} / \mathrm{L}$. The yield of glutamine and glutamate increased and decreased alternately after $20 \mathrm{~h}$ of fermentation, which was due to the mutual transformation of glutamine and glutamine through the GSGOGAT pathway. After glutamate is converted to glutamine, glutamine is converted to glutamate through GOGAT and glutaminase. As a result, glutamate cannot be completely converted to glutamine, resulting in low glutamine yield and high by-product glutamate content. To solve this problem, it is necessary to knock out the GOGAT genes NCgl0181 and NCgl0182 and the glutaminase genes NCgl2395 and NCgl2500 .

The glutamine production of G-l and G-2 reached 51.5 and $53.8 \mathrm{~g} / \mathrm{L}$, which was $6.8 \%$ and $11.6 \%$ higher than that of GM34, and the glutamate content was 27.3 and $24.0 \mathrm{~g} / \mathrm{L}$, which was $10.2 \%$ and $21.1 \%$ lower than that of GM34. The alternating increase and decrease of glutamine and glutamate yield still existed, but it was weakened; the yield of glutamine increased slightly and the content of the by-product glutamate decreased slightly, suggesting that knockout of NCgl0181 or NCgl2395alone weakens the metabolic pathway for the conversion of glutamine to glutamate. Furthermore, NCgl0181 and NCgl2395 were knocked out simultaneously, and the strain G-3 was constructed. The glutamine yield of G-3 reached $68.2 \mathrm{~g} / \mathrm{L}$, which was $41.5 \%$ higher than that of GM34; and the content of glutamate was $19.3 \mathrm{~g} / \mathrm{L}$, which was $36.5 \%$ lower than that of GM34. The alternating increase and decrease of glutamine and glutamate yield were not obvious. This shows that when NCgl0181 and NCgl2395 are knocked out at the same time, the resulting glutamine is hardly converted to glutamate, and more glutamate is converted to glutamine. However, the content of glutamate in the fermentation broth remained very high, which is speculated to be due to the low activity 
of GS, and the glutamate produced in the cells cannot be converted into glutamine in time. To further increase the yield of glutamine and reduce the content of glutamate, it is necessary to further optimise the GS-GOGAT pathway and enhance the activity of GS.

\subsubsection{Effect of the overexpression of the heterologous GS gene on glutamine fermentation}

GS in C. glutamicum is affected by adenosine acetylation. The principle of action is that AMP combines covalently with tyrosine residues on the peptide chain to form GS (AMP), and the adenylation site is Tyr405. Once adenosine acylation occurs, the activity of GS catalysing the conversion of glutamate to glutamine changes. There is no adenylation site in the GS of B. subtilis and L. acidophilus, thus, it is not affected by adenosine acylation.

In C. glutamicum GM34, the GOGAT gene has NCgl0182 in addition to NCgl0181, and the glutaminase gene has NCgl2500 in addition to NCgl2395. In this study, a copy of the GS gene $g \ln A_{b s u}$ from B. subtilis and a copy of $g l n A_{l c b}$ from L. acidophilus were integrated into the genomic NCgl0182 and NCgl2500 sites of strain G-3, respectively, and the strong promoter tuf was used to express $g \ln A_{b s u}$ and $g \ln A_{l c b}$. Strains G-4 and G-5 were constructed. Furthermore, pXT01 with the strong promoter tuf was used to overexpress $g \ln A_{b s u}$ and $g \ln A_{l c b}$, respectively, and the strains G-6 and G-7 were constructed. The effects of $g \ln A$ from these two sources on glutamine production and GS activity were analysed.

\subsubsection{Effect of integrating a copy of $g \ln A_{b s u}$ and $g \ln A_{l c b}$ on glutamine fermentation}

\section{Hosted file}

image5.emf available at https://authorea.com/users/438625/articles/539774-enhancingglutamine-production-by-optimising-the-gs-gogat-pathway-in-corynebacterium-glutamicumand-nh4-limited-fermentation

Fig. 4 Effect of integrating a copy of $g \ln A_{b s u}$ and $g \ln A_{l c b}$ on bacteria growth $\left(\mathrm{OD}_{600}\right)$

As shown in Fig. 4, there was no significant difference in $\mathrm{OD}_{600}$ between G-3, G-4, and G-5, indicating that the integration of $g \ln A_{b s u}$ and $g \ln A_{l c b}$ on the genome had no adverse effect on bacterial growth.

\section{Hosted file}

image6.emf available at https://authorea.com/users/438625/articles/539774-enhancingglutamine-production-by-optimising-the-gs-gogat-pathway-in-corynebacterium-glutamicumand-nh4-limited-fermentation

Fig. 5 Effect of integrating a copy of $g \ln A_{b s u}$ and $g \ln A_{l c b}$ on glutamine and glutamate production

\section{Hosted file}

image7.emf available at https://authorea.com/users/438625/articles/539774-enhancingglutamine-production-by-optimising-the-gs-gogat-pathway-in-corynebacterium-glutamicumand-nh4-limited-fermentation

Fig. 6 Effect of integrating a copy of $g \ln A_{b s u}$ and $g l n A_{l c b}$ on glutamine synthetase (GS) activity

As shown in Fig. 5 and 6, the glutamine production of G-4 and G-5 reached 71.6 and $74.8 \mathrm{~g} / \mathrm{L}$, which was $5.0 \%$ and $9.7 \%$ higher than that of G-3; the content of glutamate was 15.7 and $13.5 \mathrm{~g} / \mathrm{L}$, which was $18.7 \%$ and $30.1 \%$ lower than that of G-3; the GS activity of G-4 and G-5 was significantly higher than that of G-3, and the GS activity of G-5 was slightly higher than that of G-4. This proved thatgln $A_{b s u}$ and $g l n A_{l c b}$ can be expressed in C. glutamicum and play a positive role in the production of glutamine. The increase in GS activity results in more conversion of glutamate to glutamine and reduces the production of glutamate by-products. The alternating increase and decrease of glutamine and glutamate production does not exist because NCgl0181 , NCgl0182 , NCgl2395, and NCgl2500genes are knocked out, and the glutamine produced in the cells is no longer converted to glutamate. The GS activity of G-3 and G-5 was relatively stable in the early stages and increased slightly in the later stages of the fermentation process. It 
is speculated that this is because, with the progression of the fermentation process, $\mathrm{NH}_{4}{ }^{+}$is consumed and the $\mathrm{NH}_{4}{ }^{+}$concentration in the later stage of fermentation will be greatly reduced, so that the GS activity will increase to some extent.

2.1.2.2 Effect of the overexpression of the heterologous GS gene by pXT01 on glutamine fermentation

\section{Hosted file}

image8.emf available at https://authorea.com/users/438625/articles/539774-enhancingglutamine-production-by-optimising-the-gs-gogat-pathway-in-corynebacterium-glutamicumand-nh4-limited-fermentation

Fig. 7 Effect of the overexpression of the heterologous GS gene by pXT01 on bacteria growth $\left(\mathrm{OD}_{600}\right)$

As shown in Fig. 7, the bacterial growth of G-5, G-6, and G-7 was roughly the same, and the OD $_{600}$ of G-5 was slightly higher than that of G-6 and G-7 in the later stage of fermentation. This shows that the overexpression of these two heterologous GS genes in C. glutamicum did not reduce bacterial activity.

\section{Hosted file}

image9.emf available at https://authorea.com/users/438625/articles/539774-enhancingglutamine-production-by-optimising-the-gs-gogat-pathway-in-corynebacterium-glutamicumand-nh4-limited-fermentation

Fig. 8 Effect of the overexpression of the heterologous GS gene by pXT01 on the production of glutamine and glutamate

\section{Hosted file}

image10.emf available at https://authorea.com/users/438625/articles/539774-enhancingglutamine-production-by-optimising-the-gs-gogat-pathway-in-corynebacterium-glutamicumand-nh4-limited-fermentation

Fig. 9 Effect of the overexpression of the heterologous GS gene by pXT01 on glutamine synthetase activity

As shown in Fig. 8 and 9, the glutamine production of G-6 and G-7 reached 84.3 and $80.8 \mathrm{~g} / \mathrm{L}$, which was $12.7 \%$ and $8.0 \%$ higher than that of G-5, and the content of glutamate was 9.9 and $10.6 \mathrm{~g} / \mathrm{L}$, which was $26.7 \%$ and $21.5 \%$ lower than that of G-5. The GS activity of G-5, G-6, and G-7 fluctuated in the middle and early stages of fermentation and increased slightly in the later stages. Among them, the GS activity of G-6 and G-7 was significantly higher than that of G-5, and G-6 was the highest of the three. The glutamine yield of G-6 was the highest and the glutamate content was the lowest. This indicated that GS activity significantly affected glutamine fermentation. The higher the GS activity, the more glutamate was converted to glutamine; thus, the higher the glutamine yield, the less glutamate produced. Among them, the GS gene $g \ln A_{b s u}$ from B. subtilis had higher enzyme activity in $C$. glutamicum, and the production performance of G-6 was better than that of G-7. The following fermentation experiments were carried out using G-6.

\subsection{Effect of the $\mathrm{NH}_{4}{ }^{+}$-limited fermentation process on glutamine fermentation}

\subsubsection{Effect of the feeding start time of $\left(\mathrm{NH}_{4}\right)_{2} \mathrm{SO}_{4}$ on glutamine fermentation}

Through the above genetic modification to optimise the GS-GOGAT pathway, the yield of glutamine was greatly increased, and the content of glutamate was greatly decreased. Although the heterologous GS gene is not affected by adenosine acylation, the enzyme activity is inhibited by high concentrations of $\mathrm{NH}_{4}{ }^{+}$, thus, it cannot fully play its catalytic role. To further increase the yield of glutamine, it is necessary to optimise the glutamine fermentation process, explore the effect of $\mathrm{NH}_{4}{ }^{+}$concentration on glutamine fermentation, and regulate the $\mathrm{NH}_{4}{ }^{+}$concentration. In common glutamine fermentation, the addition of a large amount of $\mathrm{NH}_{4}{ }^{+}$inhibited not only the bacterial activity, but also the activity of GS. In this study, an $\mathrm{NH}_{4}{ }^{+}$-limited fermentation process was designed in which $350 \mathrm{~g}$ of $\left(\mathrm{NH}_{4}\right)_{2} \mathrm{SO}_{4}$ (dissolved in $700 \mathrm{~mL}$ of water) was fed 
uniformly at the beginning of 0,2 , and $4 \mathrm{~h}$ of fermentation until the end of fermentation, and the differences among the three were compared.

Because the side chain of glutamine contains an amide group, the amide group is not protonated within the physiological $\mathrm{pH}$ range, so the side chain of glutamine is not charged. Glutamate contains two carboxyl groups, and the carboxyl group on the side chain also dissociates completely at around $\mathrm{pH} 7$, so the molecule of glutamic acid is negatively charged. The $\mathrm{pH}$ of the fermentation broth was adjusted with $10 \% \mathrm{NaOH}$. When measuring the concentration of $\mathrm{NH}_{4}{ }^{+}$in fermentation broth, the measured value is the concentration of $\mathrm{NH}_{4}+$ ionised by $\left(\mathrm{NH}_{4}\right)_{2} \mathrm{SO}_{4}$.

\section{Hosted file}

image11.emf available at https://authorea.com/users/438625/articles/539774-enhancingglutamine-production-by-optimising-the-gs-gogat-pathway-in-corynebacterium-glutamicumand-nh4-limited-fermentation

Fig. 10 Effect of fermentation at 0,2 , and $4 \mathrm{~h}$, beginning with uniform flow and disposable addition of $\left(\mathrm{NH}_{4}\right)_{2} \mathrm{SO}_{4}$ on bacterial growth $\left(\mathrm{OD}_{600}\right)$

As shown in Fig. 9, the number of bacteria in the three uniform feeding strategies was higher than that when $350 \mathrm{~g}$ of $\left(\mathrm{NH}_{4}\right)_{2} \mathrm{SO}_{4}$ was added to the medium at one time. Among them, the number of bacteria was the highest when $\left(\mathrm{NH}_{4}\right)_{2} \mathrm{SO}_{4}$ was added at $4 \mathrm{~h}$, and the highest value of $\mathrm{OD}_{600}$ reached 121.8 , which was $24.8 \%$ higher than that for the one-time addition of culture medium $\left(\mathrm{NH}_{4}\right)_{2} \mathrm{SO}_{4}$.

The number of bacteria reflects the growth activity of the bacteria. In the logarithmic growth phase of fermentation, it can be seen that the accumulation of bacteria is faster and the bacterial activity is better under the strategy of uniform feeding $\left(\mathrm{NH}_{4}\right)_{2} \mathrm{SO}_{4}$. This is because adding a large amount of $\left(\mathrm{NH}_{4}\right)_{2} \mathrm{SO}_{4}$ at one time makes the concentration of $\mathrm{NH}_{4}{ }^{+}$in the fermentation broth very high and has an inhibitory effect on bacteria growth, while the uniform addition of $\left(\mathrm{NH}_{4}\right)_{2} \mathrm{SO}_{4}$ keeps the concentration of $\mathrm{NH}_{4}{ }^{+}$in the fermentation process at a low level. In particular, the logarithmic growth phase is an important stage of bacteria growth, and the accumulation of more bacteria in the logarithmic growth phase will lead to higher acid production efficiency in the acid production period.

\section{Hosted file}

image12.emf available at https://authorea.com/users/438625/articles/539774-enhancingglutamine-production-by-optimising-the-gs-gogat-pathway-in-corynebacterium-glutamicumand-nh4-limited-fermentation

Fig. 11 Effect of fermentation at 0,2 , and $4 \mathrm{~h}$, beginning with uniform flow and disposable addition of $\left(\mathrm{NH}_{4}\right)_{2} \mathrm{SO}_{4}$ on glutamine yield and glutamate content

\section{Hosted file}

image13.emf available at https://authorea.com/users/438625/articles/539774-enhancingglutamine-production-by-optimising-the-gs-gogat-pathway-in-corynebacterium-glutamicumand-nh4-limited-fermentation

Fig. 12 Effects of fermentation at 0,2 , and $4 \mathrm{~h}$, beginning with uniform flow and disposable addition of $\left(\mathrm{NH}_{4}\right)_{2} \mathrm{SO}_{4}$ on $\mathrm{NH}_{4}{ }^{+}$concentration and glutamine synthase activity

Combined with Fig. 11 and 12, it can be seen that the glutamine yield was the highest and the glutamate content was the lowest when $\left(\mathrm{NH}_{4}\right)_{2} \mathrm{SO}_{4}$ was fed at $0 \mathrm{~h}$ of fermentation. The yield of glutamine reached $91.4 \mathrm{~g} / \mathrm{L}$ and the content of glutamate reached $7.3 \mathrm{~g} / \mathrm{L}$. The time of glutamine production was earlier than that of the other three strategies, reaching $1.8 \mathrm{~g} / \mathrm{L}$ at $4 \mathrm{~h}$, and almost no yield at $4 \mathrm{~h}$ for the other three strategies. The $\mathrm{NH}_{4}{ }^{+}$concentrations of the three uniform feeding strategies were almost the same at $0 \mathrm{~h}$ and different at $4 \mathrm{~h}$, and the $\mathrm{NH}_{4}{ }^{+}$concentrations were $7.8,6.4$, and $5.1 \mathrm{mmol} / \mathrm{L}$, respectively. This showed 
that the concentration of $\mathrm{NH}_{4}{ }^{+}$in the early stage of fermentation affects the formation time of glutamine, and too low a concentration of $\mathrm{NH}_{4}{ }^{+}$will delay the formation time of glutamine.

The GS activity of the three strategies of uniform feeding $\left(\mathrm{NH}_{4}\right)_{2} \mathrm{SO}_{4}$ was much higher than that of adding $\left(\mathrm{NH}_{4}\right)_{2} \mathrm{SO}_{4}$ at one time. When $350 \mathrm{~g}$ of $\left(\mathrm{NH}_{4}\right)_{2} \mathrm{SO}_{4}$ was added to the medium at one time, the $\mathrm{NH}_{4}{ }^{+}$ concentration reached $5453 \mathrm{mmol} / \mathrm{L}$ at $0 \mathrm{~h}$ of fermentation. The $\mathrm{NH}_{4}{ }^{+}$concentration of the uniform feed $\left(\mathrm{NH}_{4}\right)_{2} \mathrm{SO}_{4}$ strategy was not higher than $20 \mathrm{mmol} / \mathrm{L}$ throughout the fermentation process, indicating that a high concentration of $\mathrm{NH}_{4}{ }^{+}$in the fermentation broth inhibits GS activity. The GS activity in the whole fermentation process was at a low level, thus, affecting glutamine synthesis.

The $\mathrm{NH}_{4}{ }^{+}$concentration of the three uniform feed $\left(\mathrm{NH}_{4}\right)_{2} \mathrm{SO}_{4}$ strategies was near $10 \mathrm{mmol} / \mathrm{L}$ or lower than $10 \mathrm{mmol} / \mathrm{L} 20 \mathrm{~h}$ before fermentation, and their GS activity was at a high level, with almost no difference and only a small fluctuation. After $24 \mathrm{~h}$ of fermentation, the concentration of $\mathrm{NH}_{4}{ }^{+}$began to increase and the activity of GS began to decrease. At the end of $36 \mathrm{~h}$ of fermentation, the concentration of $\mathrm{NH}_{4}{ }^{+}$reached more than $16 \mathrm{mmol} / \mathrm{L}$, and GS activity was the lowest in the fermentation process.

There are two reasons for the decrease in GS activity in the middle and later stages of fermentation. First, with the ageing of bacteria, the rate of $\mathrm{NH}_{4}{ }^{+}$consumption slows, and the concentration of $\mathrm{NH}_{4}{ }^{+}$increases gradually, which inhibits the activity of GS. Second, the bacteria ageing in the middle and later stages of fermentation will decrease the expression ability of a variety of enzymes, and the activity of GS will also be affected. It can be concluded that controlling the concentration of $\mathrm{NH}_{4}{ }^{+}$in the fermentation broth is the key to glutamine fermentation.

To sum up, the best effect was found by evenly feeding $\left(\mathrm{NH}_{4}\right)_{2} \mathrm{SO}_{4}$ at $0 \mathrm{~h}$ of fermentation, which was used in the following experiments.

\subsubsection{Effects of intermittent and gradient feed $\left(\mathrm{NH}_{4}\right)_{2} \mathrm{SO}_{4}$ strategies on glutamine fermentation}

It can be seen from Fig. 11 and 12 that the activity of GS is at a high level when the concentration of $\mathrm{NH}_{4}{ }^{+}$is less than $10 \mathrm{mmol} / \mathrm{L}$ in the early stage of fermentation at $0-4 \mathrm{~h}$, but too little $\mathrm{NH}_{4}{ }^{+}$is not conducive to the conversion of glutamate to glutamine, and even delays the glutamine production time. At about $12-20 \mathrm{~h}$ after fermentation, when the $\mathrm{NH}_{4}{ }^{+}$concentration was around $10 \mathrm{mmol} / \mathrm{L}$, GS activity reached the highest, and the glutamine acid production rate also reached the peak value. Although the strategy of uniform feeding of $\left(\mathrm{NH}_{4}\right)_{2} \mathrm{SO}_{4}$ greatly improved the GS activity, the $\mathrm{NH}_{4}{ }^{+}$concentration increased gradually in the middle and late stage of fermentation, and the $\mathrm{NH}_{4}{ }^{+}$concentration increased from around 10 to over $16 \mathrm{mmol} / \mathrm{L}$, while the GS activity decreased gradually. In view of the shortcomings of uniform feeding of $\left(\mathrm{NH}_{4}\right)_{2} \mathrm{SO}_{4}$, this study also designed two strategies: intermittent feeding and gradient feeding of $\left(\mathrm{NH}_{4}\right)_{2} \mathrm{SO}_{4}$, both of which fed $350 \mathrm{~g}$ of $\left(\mathrm{NH}_{4}\right)_{2} \mathrm{SO}_{4}$ (dissolved in $700 \mathrm{~mL}$ of water) at the beginning of fermentation at $0 \mathrm{~h}$.

The intermittent feeding method: 0-4 h uniform feed $140 \mathrm{~mL}\left(\mathrm{NH}_{4}\right)_{2} \mathrm{SO}_{4}, 4-8 \mathrm{~h}$ stop feeding, and so on until the end of fermentation. The gradient feedingmethod: 0-12 h uniform feed $200 \mathrm{~mL}\left(\mathrm{NH}_{4}\right)_{2} \mathrm{SO}_{4}, 12-24 \mathrm{~h}$ uniform feed $350 \mathrm{~mL}\left(\mathrm{NH}_{4}\right)_{2} \mathrm{SO}_{4}$, and 24-36 h uniform feed $150 \mathrm{~mL}\left(\mathrm{NH}_{4}\right)_{2} \mathrm{SO}_{4}$.

\section{Hosted file}

image14.emf available at https://authorea.com/users/438625/articles/539774-enhancingglutamine-production-by-optimising-the-gs-gogat-pathway-in-corynebacterium-glutamicumand-nh4-limited-fermentation

Fig. 13 Effects of three $\left(\mathrm{NH}_{4}\right)_{2} \mathrm{SO}_{4}$ flow addition methods on bacterial growth $\left(\mathrm{OD}_{600}\right)$

As shown in Fig. 13, the growth of bacteria in the three $\left(\mathrm{NH}_{4}\right)_{2} \mathrm{SO}_{4}$ feeding modes was roughly the same, which indicates that the $\left(\mathrm{NH}_{4}\right)_{2} \mathrm{SO}_{4}$ feeding mode had no influence on the growth of bacteria.

\section{Hosted file}

image15.emf available at https://authorea.com/users/438625/articles/539774-enhancingglutamine-production-by-optimising-the-gs-gogat-pathway-in-corynebacterium-glutamicum- 
and-nh4-limited-fermentation

Fig. 14 Effects of three $\left(\mathrm{NH}_{4}\right)_{2} \mathrm{SO}_{4}$ flow addition methods on glutamine yield and glutamate content

\section{Hosted file}

image16.emf available at https://authorea.com/users/438625/articles/539774-enhancingglutamine-production-by-optimising-the-gs-gogat-pathway-in-corynebacterium-glutamicumand-nh4-limited-fermentation

Fig. 15 Effect of three $\left(\mathrm{NH}_{4}\right)_{2} \mathrm{SO}_{4}$ flow methods on $\mathrm{NH}_{4}{ }^{+}$concentration and activity of glutamine synthase in fermentation fluid

As shown in Fig. 14, the glutamine yields of intermittent and gradient feeding strategies reached 95.6 and 98.7 $\mathrm{g} / \mathrm{L}$, which were $4.6 \%$ and $8.0 \%$ higher than those of uniform feeding. Glutamate content is 6.7 and $4.5 \mathrm{~g} / \mathrm{L}$, which is $8.2 \%$ and $38.4 \%$ lower than that of uniform feeding. As shown in Fig. 15, the $\mathrm{NH}_{4}{ }^{+}$concentration in the fermentation broth of the intermittent feeding strategy fluctuates greatly, ranging from 10 to $14 \mathrm{mmol} / \mathrm{L}$, and the GS activity in the early stage of fermentation is not much different from that of the uniform feeding strategy. After $36 \mathrm{~h}$ of fermentation, the final concentration of $\mathrm{NH}_{4}{ }^{+}$reached $13.7 \mathrm{mmol} / \mathrm{L}$, which was lower than $16.2 \mathrm{mmol} / \mathrm{L}$ of the uniform feeding strategy, and the GS activity was $37.4 \%$ higher than that of the uniform feeding strategy. The $\mathrm{NH}_{4}{ }^{+}$concentration in the fermentation broth was stable at about 10 $\mathrm{mmol} / \mathrm{L}$ from $4 \mathrm{~h}$ to the end of fermentation, with little fluctuation. After $36 \mathrm{~h}$ of fermentation, only the final concentration of $\mathrm{NH}_{4}{ }^{+}$in the gradient feeding strategy was approximately $10 \mathrm{mmol} / \mathrm{L}$. The GS activity was at a high level throughout the process, which was higher than $4000 \mu \mathrm{mol} / \mathrm{h} / \mathrm{g}$ fresh weight, and decreased slightly in the later period, but was always higher than the uniform and intermittent feeding strategies in the middle and later period of fermentation, especially in the later period. According to the characteristics of acid production and $\mathrm{NH}_{4}{ }^{+}$consumption rates of bacteria in glutamine fermentation, gradient feeding of $\left(\mathrm{NH}_{4}\right)_{2} \mathrm{SO}_{4}$ into culture medium can maintain the $\mathrm{NH}_{4}{ }^{+}$concentration in the fermentation broth at about $10 \mathrm{mmol} / \mathrm{L}$, and GS activity is at a high level, which is superior to the other two feeding methods and is most suitable for glutamine fermentation. To sum up, the $\mathrm{NH}_{4}{ }^{+}$-limited fermentation process adopts the strategy of gradient feeding of $350 \mathrm{~g}$ of $\left(\mathrm{NH}_{4}\right)_{2} \mathrm{SO}_{4}$.

\subsection{Effects of optimising the GS-GOGAT pathway and $\mathrm{NH}_{4}{ }^{+}$-limited fermentation process on the sugar-acid conversion rate}

\section{Hosted file}

image17.emf available at https://authorea.com/users/438625/articles/539774-enhancingglutamine-production-by-optimising-the-gs-gogat-pathway-in-corynebacterium-glutamicumand-nh4-limited-fermentation

Fig. 16 Comparison of the sugar-acid conversion rate of glutamine fermentation in this study

Note: 0,2 , and $4 \mathrm{~h}$ on the $\mathrm{x}$-axis represent uniform feeding $\left(\mathrm{NH}_{4}\right)_{2} \mathrm{SO}_{4}$ at 0,2 , and $4 \mathrm{~h}$ after the beginning of fermentation.

As shown in Fig. 16, the sugar-acid conversion rate of GM34 was the lowest (32.5\%). Because it produces a large amount of the by-product glutamate, the conversion efficiency of glucose to glutamine was very low. By optimising the GS-GOGAT pathway, the glutamate content was greatly reduced, and the sugaracid conversion rates of G-6 and G-7 reached $37.1 \%$ and $37.3 \%$ respectively. Using $\left(\mathrm{NH}_{4}\right)_{2} \mathrm{SO}_{4}$ uniform, intermittent, and gradient feeding strategies, the content of glutamate was further decreased, the yield of glutamine was further increased, and the sugar-acid conversion rate reached $40.8 \%, 40.5 \%$, and $41.2 \%$. Among them, the $\left(\mathrm{NH}_{4}\right)_{2} \mathrm{SO}_{4}$ gradient feeding strategy with higher glutamine yield and lowest glutamate content had the highest sugar-acid conversion rate, which was $26.7 \%$ higher than that of the original strain GM34.

\section{Conclusion}


To increase the glutamine yield and reduce glutamate content, the GS-GOGAT pathway was optimised by knocking out GOGAT genesNCgl0181 and NCgl0182 and glutaminase genesNCgl2395 and NCgl2500 , and overexpressing glutamine synthase genes $g l n A_{b s u}$ and $g l n A_{l c b}$ from B. subtilis and L. acidophilus. The strain G-6 with the strongest glutamine production capacity was obtained, and the $\mathrm{NH}_{4}{ }^{+}$-limited fermentation process was designed. As a result, the best feeding strategy of gradient feed $\left(\mathrm{NH}_{4}\right)_{2} \mathrm{SO}_{4}$ was obtained. The enzyme activity of GS was improved by controlling the concentration of $\mathrm{NH}_{4}{ }^{+}$in the fermentation broth. The yield of glutamine was increased from 48.2 to $98.7 \mathrm{~g} / \mathrm{L}$, the content of glutamate was reduced from 30.4 to $4.5 \mathrm{~g} / \mathrm{L}$, the activity of GS was greatly increased, and the sugar-acid conversion rate was increased from $32.5 \%$ to $41.2 \%$. Wu Sifang of the Hubei University of Technology screened L-glutamine high-yield strain SH44 from the original strain C. glutamicum S9114 by using the methods of $\gamma$-ray-diethyl sulfate- $\gamma$-ray compound mutagenesis and sulpha-resistant directional breeding, and the yield of L-glutamine reached $55.3 \mathrm{~g} / \mathrm{L}$. Wu Sifanget al . optimised the type and concentration of nitrogen sources, metal ions, and $\mathrm{CaCO}_{3}$ of the culture medium, so that the average L-glutamine production of the strain SH77 reached $53.0 \mathrm{~g} / \mathrm{L}$ and the highest was $56.2 \mathrm{~g} / \mathrm{L}$, which is the highest yield of L-glutamine reported to date. In this study, compared with mutagenesis and resistance-oriented breeding, the method of genetic modification was more purposeful and can improve the production capacity of the strain more obviously. Compared with the traditional fermentation medium optimisation, the $\mathrm{NH}_{4}{ }^{+}$-limited fermentation process not only combines the characteristics of the optimised GS-GOGAT pathway, but also detects the GS activity and $\mathrm{NH}_{4}{ }^{+}$concentration in real-time. These two factors are the key parameters of L-glutamine fermentation. The relationship between these factors and their influence on glutamine production were analysed, the best $\left(\mathrm{NH}_{4}\right)_{2} \mathrm{SO}_{4}$ feeding strategy was designed, and the $\mathrm{NH}_{4}{ }^{+}$-limited fermentation process was obtained, which provides a new idea for L-glutamine industrialisation.

\section{References}

1. Souba Wiley W.. Intestinal glutamine metabolism and nutrition[J]. 1993, 4(1) : 2-9.

2. Philip C Calder. More good news about glutamine[J]. Nutrition, 2000, 16(1) : 71-73.

3. Reeds, Peter, J, et al. Glutamine and the Bowel.[J]. Journal of Nutrition, 2001.

4. Rennie Michael J. et al. Glutamine Metabolism and Transport in Skeletal Muscle and Heart and Their Clinical Relevance[J]. The Journal of Nutrition, 1996, 126(suppl4) : 1142S-1149S.

5. Josef $\mathrm{N}$. Glutamine in the fetus and critically ill low birth weight neonate: metabolism and mechanism of action.[J]. Journal of Nutrition, 2001(9):2585S.

6. Karinch Anne M. et al. Glutamine Metabolism in Sepsis and Infection[J]. The Journal of Nutrition, 2001, 131(9) : 2535S-2538S.

7. Newsholme Philip. Why Is L-Glutamine Metabolism Important to Cells of the Immune System in Health, Postinjury, Surgery or Infection?[J]. 2001, 131(9) : 2515S-2522S.

8. Medina M A . Glutamine and Cancer[J]. Journal of Nutrition, 131(9 Suppl):2539S.

9. Haluk Ertan. The effect of various culture conditions on the levels of ammonia assimilatory enzymes of Corynebacterium callunae[J]. Archives of Microbiology, 1992, 158(1) : 42-47.

10. Martin Tesch et al. Ammonia assimilation in Corynebacterium glutamicum and a glutamate dehydrogenase-deficient mutant[J]. Biotechnology Letters, 1998, 20(10) : 953-957.

11. Takashi Tachiki et al. Glutamine Synthetase from Micrococcus glutamicus : Effect of Nitrogen Sources in Culture Medium on Enzyme Formation and Some Properties of Crystalline Enzyme[J]. Agricultural and Biological Chemistry, 2014, 45(6) : 1487-1492.

12. Meng G Z , Hao F X, Qian S J . [Regulation of Corynebacterium pekinense glutamine synthetase by the carbon and nitrogen source][J]. Acta Microbiologica Sinica, 1986, 26(3):238.

13. Tesch M, Graaf A D, Sahm H . In Vivo Fluxes in the Ammonium-Assimilatory Pathways in Corynebacterium glutamicum Studied by 15N Nuclear Magnetic Resonance[J]. Applied \& Environmental Microbiology, 1999, 65(3):1099.

14. Schulz Anton A and Collett Helen J and Reid Sharon J. Nitrogen and carbon regulation of glutamine synthetase and glutamate synthase in Corynebacterium glutamicum ATCC 13032[J]. FEMS Microbiology Letters, 2006, 205(2) : 361-367. 
15. Merrick M J , Edwards R A . Nitrogen control in bacteria.[J]. Microbiol Rev, 1995, 59(4):604-622.

16. Luo Shen and Kim Geumsoo and Levine Rodney L. Mutation of the adenylylated tyrosine of glutamine synthetase alters its catalytic properties.[J]. Biochemistry, 2005, 44(27) : 9441-6.

17. J Strösser, A Lüdke, Schaffer S, et al. Regulation of GlnK activity: modification, membrane sequestration and proteolysis as regulatory principles in the network of nitrogen control in Corynebacterium glutamicum[J]. Molecular Microbiology, 2010, 54(1):132-147. 